$\begin{array}{r}\text { Volume and Issues Obtainable at Center for Sustainability Research and Consultancy } \\ \text { Journal of Business and Social Review in Emerging Economies } \\ \text { ISSN: 2519-089X (E): 2519-0326 } \\ \text { Volume 6: No. 4, December } 2020 \\ \text { JSRC } \\ \text { Journal homepage: www.publishing.globalcsrc.org/jbsee } \\ \hline\end{array}$

\title{
Relationship between Time Management Behavior and Academic Performance of University Students
}

\author{
${ }^{1}$ Abdur Rashid, ${ }^{2}$ Ilyas Sharif, ${ }^{3}$ Shakeel Khan, ${ }^{4}$ Fazal Malik \\ ${ }^{1}$ Lecturer, Department of Education, Shaheed Benazir Bhutto University, Sheringal Dir Upper, Pakistan \\ ${ }^{2}$ Lecturer, Quaid-e-Azam College of Commerce, University of Peshawar, Pakistan, \\ ilyasqacc@uop.edu.pk \\ ${ }^{3}$ Lecturer Institute of Management Studies, University of Peshawar, Pakistan \\ ${ }^{4}$ PhD Scholar, Management Science, Qurtuba University of Science and Technology, Peshawar, \\ Pakistan
}

\begin{tabular}{l}
\hline ARTICLE DETAILS \\
\hline History \\
Revised format: November \\
2020 \\
Available Online: December \\
2020 \\
\hline Keywords \\
Time Management Behaviour, \\
Under Graduate Students, \\
Public Sector Universities, \\
CGPA
\end{tabular}

JEL Classification

MO, $M 1$

\begin{abstract}
Effective time management leads to greater academic performance and reduces stress, strain and anxiety among students, however, students facing difficulties to keep a balance between their academic life and personal-social life. This study aims to examine the self-perceptions of undergraduate students' time management behaviour by using Time Management Behaviour Scale (TMBS) developed by Macan, Shahani, Dipboye and Phillips (1990). The scale consisted of 34 rating items ranges from very often true to seldom true. The population of the study consisted of all undergraduate students studying in the academic session 2018-19 at public sector general category universities in Malakand division. By using stratified sampling technique a sample of 1050 undergraduate students were selected from the sampled universities. Students were also asked to provide their CGPA in their previous semester. Both descriptive and inferential statistics were used to analyze the data. It was found that prospective teachers have moderate to high level of time management skills. Significant relationship was found between undergraduate students' time management behaviour and academic performance. It was recommended that university administration should orient students to enhance their time management behaviour by arranging seminars, workshops and conferences to enhance their time management skills.
\end{abstract}

(C) 2020 Center for Sustainability Research and Consultancy Pakistan under a Creative Commons Attribution-NonCommercial-ShareAlike

4.0

Corresponding author's email address: ilyasqacc@uop.edu.pk

Recommended citation: Rashid, A., Sharif, I, Khan, S. \& Malik, F. (2020). Relationship between Time Management Behavior and Academic Performance of University Students. Journal of Business and Social Review in Emerging Economies, 6(4), 1497-1504 


\section{Introduction}

Balduf (2009) recognized that poor time management leads to academic underachievement while Britton and Tesser (1991) mentioned as good time management guarantees higher academic achievement of college students. Further, they found that $67 \%$ undergraduate students perceived time management as their most crucial problem. Moreover, they found that self-reported time management predicts academic achievement and particularly short-range planning predict grade point average of college students. George, Dixon, Stansal, Gelb and Pheri (2008) recognized that good time management skills may be proved as key to academic success. They found that time management is a significant predictor of academic achievement. In addition, they found that time management is the sole predictor of university students CGPA and also related to academic and personal success. Similarly, Misra and McKean (2000) stated that strategies adopted by students aimed to improve their effective utilization of time are recommended as support to increase academic achievement. They also found a negative correlation between time management and academic stress. Rabin, Fogel and Nutter-Upham (2011) found that 30\% to $60 \%$ undergraduate university students regularly post pone their academic tasks. Similarly, Seo (2012) mentioned that undergraduate university students usually cram and "pulling and nighters" before an academic task. Hess, Sherman and Goodman (2000) mentioned that procrastination is also predictor of academic achievement.

Time is one of the precious resources that higher education intuitions students must possess. The way through which individuals manage their time may influence their academic performance (Claessens, Van Eerde, Rutte, \& Roe, 2004). Effective time management leads to greater academic performance and reduces stress, strain and anxiety among students, however, students facing difficulties to keep a balance between their academic life and personal-social life (Adams \& Blair 2019). The way through which students manage their time may influence their academic achievement, personal and social life and future or employment life (Macan et al., 1990; Britton \& Tesser, 1991; Kearns \& Gardiner, 2007). Thus it is very essential for the students to allocate and manage their time and meet the deadlines (Al Khatib, 2014).

Some universities in the world offer time management training programmes for their students during their studies (Covic, Adamson, Lincoln, \& Kench, 2003). The main purpose of such initiatives is to improve their learning and grades. Grades or marks in the universities depend on the completion of different varieties of tasks. These tasks may be completed in a given time framework or deadline, including the length or period of the task and priorities of the task. Grades or marks are given to the students on the basis of completion of these multiple tasks depending on their quality and effort put in by the students. Britton and Tesser (1991) rightly pointed that students' marks or their grade point average would be expected to be influenced by their time management skills. Thus students need to be conscious to manage their time effectively and efficiently to obtain high grades. Both Macan et al., (1990) and Britton and Tesser (1991) found that students' time management ability is directly related to their academic performance. Generally, a student with successful and productive time management skill would have better grades and experience less stress related to their academic life. Britton and Tesser (1991) concluded that university students' time management skills accounted for $36 \%$ of the variance with their grade point average. Macan et al., (1990) concluded that college students with more perceived control of time found to be more satisfied than those who haven't control over time. Macan (1994) claimed that practices like setting goals, scheduling events, making to-do list and preferences for organization enable an individual to gain mastery over how they utilize their time.

The literature shows mixed findings regarding the relationship between students' time management skills and their academic achievement. Many studies have been conducted in different fields and levels of education including medical, engineering, general college students, business students, school students and university students but no single study has been conducted in the local setting to find out the relationship between undergraduate students' time management on their academic achievement. To fill this gap in the existing literature, the present study has been sought to seek the answers of the following 
research questions.

1. What is the time management behaviour level of undergraduate students in public sector universities of Malakand division?

2. What is the extent of relationship between students' time management behaviour and academic achievement?

\section{Research Methodology}

The present study was based on quantitative (descriptive survey) research design. Cross-sectional survey design was used to collect data from the respondents. As the study focused on seeking undergraduate students' time management level level and also finds the relationship between students' time management behaviour and their academic achievement, therefore, correlational research design was used to analyze the data. Thus it was a cross-sectional survey and analytical in nature (Cohen, Manion, \& Morrison, 2007). From scattered population survey is considered the best way to gather information from the respondents in an analytical study because it allows the researcher to find the relationship that exist between variables to be studied (Bryman, 2008; Cohen, Manion, \& Morrison, 2013). Therefore, the researchers adopted the above stated method for collection and analysis of data in this study.

The population of the study consisted of all undergraduate students of three public sector universities of Malakand division. The sample of the study consisted of 1200 students through non-proportionate stratified sampling technique. From each university 400 undergraduate students were conveniently selected. A total number of twelve hundred survey packets (questionnaires) were distributed among undergraduate students of three public sector universities in Malakand division. Each survey packet was accompanied by a covering letter inviting participation in the survey, describing purposes of the study and ensuring confidentiality and anonymity for the institution and students. Twelve hundred filled questionnaires were received from the respondents as the researchers personally collected the data from these universities.

This study used Macan et al., (1990) four factors scale which has been widely used by different researchers in different parts of the world to measure students' perception about time management behaviour. There were many reasons of using this scale as it is an easy, understandable, valid, and reliable and used by dozen of researchers to measure the time management behaviour of the school, college and university students of different fields like medical, engineering, business, petroleum and general students. For convenience of the students the scale was translated into Urdu language, so that students can understand it and would be able to understand the concepts and give exact response. This scale has four factors related to setting goals and priorities, mechanics of scheduling and planning, preference for organization, and perceived control of time. The scale consisted of 35 five points Likert scale ranging from "seldom true" to "very often true". Out of 34 items 10 items were related to the first factor setting goals and priorities, 11 were related to the second factor mechanics of scheduling and planning, 08 items were related to the third factor preferences for organization and 05 items were related to perceived control of time.

As it was an adopted questionnaire and has been used by different researchers in different fields in different countries of the world. Therefore, it is a valid questionnaire. The questionnaire was first pilot tested on students in a university and responses were found satisfactory. Participants were asked to respond on Five-Point Likert scale ranging from "seldom true" to "very often true" having values of 5, $4,3,2$, and 1 respectively. The Cronbach alpha value (.83) for the pilot test indicated that the instrument was highly reliable. The reliability values for TMBS were found more than 0.70 thresholds, which show satisfactory level of statistical testing for social sciences (Cohen et al., 2007: 506; Tesfaw, 2014).

\section{Data Analysis}

The researchers analyzed the collected data by using both descriptive and inferential statistical tests. In descriptive statistics the researchers used mean scores of each dimension and overall scores of students' 
time management behaviour; and standard deviation of each dimension and overall scores of students' time management behaviour were used. As the data was showing normal curve distribution, therefore, the researchers used Pearson's Product-Moment co-efficient correlation ( $r$ ) was used as inferential statistics. To interpret the mean scores, the researcher used mean score 3.0 as midpoint mark (Iqbal, 2010; Ghazi, 2004; Nguni, 2005: 125; Hukpati, 2009: 34; Tesfaw, 2014). It was assumed by the researchers that the item or dimension which has mean score greater than midpoint 3.0 demonstrate the evidence of students' time management behaviour. Thus the item or dimension having mean score greater than the midpoint $(M>3)$, was interpreted as above average level of observance of time management behaviour. The researchers assumed that the higher the mean score, the greater the observance of time management behaviour.

The researchers also interpreted the value of Pearson product-moment correlation coefficient (r) between students' time management behaviour scores based on Field's (2009) interpretation. According to Field's (2009), the values of $r$ which lies between .10 to .29 was interpreted as weak relationship; the value of $\mathrm{r}$ lies between .30 to .49 was interpreted as moderate level; and the value of $r$ lies between .50 to 1.0 was interpreted as high or strong relationship. The researchers fed the collected data into data sheet for analysis in Statistical Package for Social Sciences (SPSS) version 22.0.

Table 01: Sample profile of the participants

\begin{tabular}{ccc}
\hline & Frequency & Percentage \\
\hline Demographic Variables & Gender & \\
\hline Male & 732 & 61 \\
Female & 468 & 39 \\
\hline & Age & 75.58 \\
\hline 20 Years & 907 & 24.42 \\
\hline 20 Years & 293 & \\
\hline & Current Semester & 25.08 \\
\hline $2^{\text {nd }}$ & 301 & 33.66 \\
$4^{\text {th }}$ & 404 & 25.58 \\
$6^{\text {th }}$ & 307 & 15.66 \\
\hline $8^{\text {th }}$ & 188 & \\
\hline
\end{tabular}

The above table represents the sample profile of the undergraduate students. Among the obtained data of 1200 students, 61 were male and 39 were female, which indicates that more male students has participated in the study. Among the sample students, 75.58 were less than or equal to the age of 20 while 24.42 have greater than 21 years old. Thus comparatively more students have participated in the study were of less than 20 years old. Out of 1200 students, $25.08 \%$ students of second semester; 33.66\% students of fourth semester; $25.58 \%$ students of sixth semester and $15.66 \%$ students of eighth semester students have participated in the study. The number of fourth semester students was found higher than that of second, sixth, and eighth semester's students respectively, who participated in the study.

Table 02: Time management behaviour level of undergraduate students

\begin{tabular}{lccc}
\hline TMBS Constructs & n & Mean & Standard Deviation \\
\hline Setting goals and priorities & 1200 & 2.69 & 0.860 \\
Mechanics of scheduling and planning & 1200 & 2.80 & 0.654 \\
Preference for organization & 1200 & 2.76 & 0.689 \\
Perceived control of time & 1200 & 2.81 & 0.792 \\
Overall TMBS & 1200 & 2.76 & 0.712 \\
\hline
\end{tabular}

The above table shows the mean and standard deviation scores of the different dimensions of students' time management behaviour. Perceptions of undergraduate students regarding "perceived control of time" were observed to have the maximum mean value (2.81) which shows that this dimension has the maximum level of observance among the four dimensions of time management behaviour. On the other hand "setting goals and priorities" was observed to have the minimum mean score (2.76) which shows the lowest level of observance among the four dimensions of time management behaviour. As the mean 
scores for different dimensions of time management behaviour was found less than the midpoint 3.0, therefore, undergraduate students' time management behaviour level have below average level of observance.

Table 03: Relationship between TMBS constructs and Academic Performance of Students

\begin{tabular}{|c|c|c|c|c|c|c|c|}
\hline \multirow{2}{*}{$\begin{array}{l}\text { Variables } \\
\text { Setting Goals } \\
\text { and Priorities }\end{array}$} & Relationship & SGP & MTM & PFO & PCT & TMBS & $\mathbf{A P}$ \\
\hline & $\begin{array}{l}\text { Pearson } \\
\text { Correlation } \\
\text { Sig. (2-tailed) } \\
\text { N }\end{array}$ & 200 & & & & & \\
\hline $\begin{array}{l}\text { Mechanics of } \\
\text { Time }\end{array}$ & $\begin{array}{l}\text { Pearson } \\
\text { Correlation }\end{array}$ & $.427^{* *}$ & 1 & & & & \\
\hline Management & $\begin{array}{l}\text { Sig. (2-tailed) } \\
\mathrm{N}\end{array}$ & $\begin{array}{l}.000 \\
199\end{array}$ & 199 & & & & \\
\hline $\begin{array}{l}\text { Preference for } \\
\text { Organization }\end{array}$ & $\begin{array}{l}\text { Pearson } \\
\text { Correlation } \\
\text { Sig. (2-tailed) } \\
\text { N }\end{array}$ & $\begin{array}{l}.662^{* *} \\
.000 \\
440\end{array}$ & $\begin{array}{l}.505^{* *} \\
.000 \\
199\end{array}$ & 200 & & & \\
\hline $\begin{array}{l}\text { Perceived } \\
\text { Control of } \\
\text { Time }\end{array}$ & $\begin{array}{l}\text { Pearson } \\
\text { Correlation } \\
\text { Sig. (2-tailed) } \\
\text { N }\end{array}$ & $\begin{array}{l}.247^{* *} \\
.000 \\
4400\end{array}$ & $\begin{array}{l}.329^{* *} \\
.000 \\
199\end{array}$ & $\begin{array}{l}.452^{* *} \\
.000 \\
200\end{array}$ & 200 & & \\
\hline $\begin{array}{l}\text { Time } \\
\text { Management } \\
\text { Behavior Scale }\end{array}$ & $\begin{array}{l}\text { Pearson } \\
\text { Correlation } \\
\text { Sig. (2-tailed) } \\
\text { N }\end{array}$ & $\begin{array}{l}.791^{* *} \\
.000 \\
199\end{array}$ & $\begin{array}{l}.716^{* *} \\
.000 \\
199\end{array}$ & $\begin{array}{l}.859^{* *} \\
.000 \\
199\end{array}$ & $\begin{array}{l}.674^{* *} \\
.000 \\
199\end{array}$ & 199 & \\
\hline $\begin{array}{l}\text { Academic } \\
\text { Performance of } \\
\text { Students }\end{array}$ & $\begin{array}{l}\text { Pearson } \\
\text { Correlation } \\
\text { Sig. (2-tailed) } \\
\text { N }\end{array}$ & $\begin{array}{l}.189^{* *} \\
.007 \\
200\end{array}$ & $\begin{array}{l}.294^{* *} \\
.000 \\
199\end{array}$ & $\begin{array}{l}.175^{*} \\
.013 \\
200\end{array}$ & $\begin{array}{l}.228^{* *} \\
.001 \\
200\end{array}$ & $\begin{array}{l}.289^{* *} \\
.000 \\
199\end{array}$ & 200 \\
\hline
\end{tabular}

$\mathrm{SGP}=$ Setting Goals and Priorities, MTM= Mechanics of Time Management, $\mathrm{PFO}=$ Preference for Organization, PCT=Perceived Control of Time, TMBS=Time Management Behavior Scale and $\mathrm{AP}=$ Academic Performance

The above table revealed the correlation matrix among different dimensions of TMBS and also the relationship of each dimension with students' academic performance. The values of co-efficient of correlation among different dimensions of TMBS were ranging from weak to strong relationship. The relationship between all dimensions of TMBS and students' academic performance were found statistically positive weak significant at the .05 level of significance. It shows that with the increase in time management behaviour of students accompanies with the increase in academic performance. In other words, the higher the level of students' time management behaviour the greater the academic achievement of the students.

\section{Discussion}

The present study found that the undergraduate students of universities have below average level of time management behaviour. The mean scores for different dimensions of the time management behaviour showed that undergraduate students have below average level of tendencies towards setting goals and priorities, mechanics of time management, preference for organization and perceived control of time. The mean score for perceived control of time was found to be greater than that of the other time management behaviour dimensions while setting goals and priorities has minimum level of observance among the four dimensions of the time management behaviour scale. This implies that undergraduate students were generally more conscious about their time use. They tried their best to complete the task within the allotted period of time. They tried to follow the schedule and do not waste time in unimportant tasks. They felt difficulty in setting goals and priorities tasks; they can't plan and manage their time for short and long term goals. Similarly, they felt difficulty in making to-do list and cannot priorities the tasks on urgency basis. As a result they failed to have good academic scores. These results 
have been testified by many researchers who found that students would like to be organized but fail to have any strategies to help themselves (Kelly, 2002; Adams \& Blair, 2019). The mean scores of the different dimensions of time management behaviour scale showed that undergraduate students have trouble with SGP, MTM, PFO and PCOT. Strategies like keeping a log of activities, keeping an appointment book, reviewing daily activities, making to-do list will help the students to plan and keep them on track to feel more in control of their time and more able to estimate the needed time to accomplish tasks (Adams \& Blair, 2019; Pozdeeva, 2019).

The study also finds positive weak significant relationship between different dimensions of time management behaviour scale and students' academic achievement. This implies that students having good time management behaviour tend to have better grades. On the other hand, students have poor time management behaviour will have low grades. The literature shows mixed findings regarding the relationship between time management and academic performance. Some researchers found direct relationship between students' time management skills and academic achievement while other has regretted the positive relationships between these two constructs. The findings of the study have been testified by many other researchers who found that time management was positively related with students academic performance (Adams \& Blair, 2019; Kearns \& Gardiner, 2007; Macan et al., 1990; McKenzie \& Gow, 2004; Trueman \& Hartley). Thus, it is evident that these times management behaviour i.e. SGP, MTM, PFO and PCOT lead to an improvement in academic performance of the students. Students having greater academic performance are better at managing their space and time.

\section{Conclusions}

Based on the findings, this study concludes that undergraduate students have below average level of time management behaviour level. Universities students find it difficult to set goals and priorities; schedule their time for different tasks; have well-organized workplace; make to-do list; feeling in control of time; being procrastinated and not able to estimate the needed time to accomplish tasks. The study also confirmed that students' time management behaviour significantly positively correlated with their academic performance. Students having better time management behaviour tend to have higher grade point average.

\section{Recommendations}

The researchers have recommended that it is the joint responsibility of the teachers, administration and policy makers to provide students an overview of the main strategies to develop enhance the time management skills of students particularly the first year students when they newly enter in a higher education setting and know less about the academic matters. The university students must study the books related to time management which may lead them to better understanding of the concept of time management strategies which may be useful to utilize their time more productively. It is suggested that university administrators must arrange seminars and workshops for students on practical tips on how to manage time for different activities in order to reduce mental stress and enhance academic performance.

\section{References}

Adams, R. V., \& Blair, E. (2019). Impact of time management behaviors on undergraduate engineering students' performance. SAGE Open, 9(1), 2158244018824506.

Al Khatib, A. S. (2014). Time Management and Its Relation to Students' Stress, Gender and Academic Achievement among Sample of Students at Al Ain University of Science and Technology, UAE. International Journal of Business and Social Research, 4(5), 47-58.

Balduf, M. (2009). Underachievement among college students. Journal of Advanced Academics, 20, 274-294.

Britton, B. K. \& Tesser, A. (1991). Effects of time-management practices on college grades. 
Bryman, A. (2008). Why do researchers integrate/combine/mesh/blend/mix/merge/fuse quantitative and qualitative research. Advances in mixed methods research, 87-100.

Claessens, B. J., Van Eerde, W., Rutte, C. G., \& Roe, R. A. (2004). Planning behavior and perceived control of time at work. Journal of Organizational Behavior: The International Journal of Industrial, Occupational and Organizational Psychology and Behavior, 25(8), 937-950.

Cohen, L., Manion, L., \& Morrison, K. (2007). Observation. Research methods in education, 6, 396412.

Cohen, L., Manion, L., \& Morrison, K. (2013). Research methods in education. Rutledge.

Covic, T., Adamson, B., Lincoln, M., \& Kench, P. (2003). Health science students' time organization and management skills: A cross-disciplinary investigation. Medical teacher, 25(1), 47-53.

Field, A. (2009). Discovering statistics using SPSS. Sage publications.

George, D., Dixon, S., Stansal, E., Gelb, S.L., \& Pheri, T. (2008). Time diary and questionnaire assessment of factors associated with academic and personal success among university undergraduates. Journal of American College Health, 56, 706-715.

Ghazi, S. R. (2004). Job Satisfaction of Elementary School Head Teachers (Toba Tek Singh) in the Punjab. . (Ph. D Thesis). Faculty of Advanced Integrated Studies and Research (Education), NUML, Islamabad, Pakistan.

Hess, B., Sherman, M. F. \& Goodman, M. (2000). Eveningness predicts academic procrastination: The mediating role of neuroticism. Journal of Social Behavior \& Personality, 15(5), 61-74.

Hukpati, C. (2009). Transformational leadership and teacher job satisfaction: A comparative study of private and public tertiary institutions in Ghana. Master's Thesis, University of Twente, Netherlands.

Iqbal, A. (2010). A Comparative Study of the Impact of Principals' Leadership Styles on the Job Satisfaction of Teachers. (Ph. D Thesis). Institute of Education \& Research, University of the Punjab, Lahore, Pakistan.

Journal of Educational Psychology, 83(3), 405-410.

Kearns, H., \& Gardiner, M. (2007). Is it time well spent? The relationship between time management behaviours, perceived effectiveness and work-related morale and distress in a university context. High Education Research \& Development, 26(2), 235-247.

Kelly, W. E. (2002). Harnessing the river of time: A theoretical framework of time use efficiency with suggestions for counselors. Journal of Employment Counseling, 39(1), 12-21.

McKenzie*, K., Gow, K., \& Schweitzer, R. (2004). Exploring first-year academic achievement through structural equation modelling. Higher Education Research \& Development, 23(1), 95-112.

Misra, R., \& McKean, M. (2000). College students' academic stress and its relation to their anxiety, time management, and leisure satisfaction. American Journal of Health Studies, 16, 41-51.

Nguni, S. C. (2005). A study of the effects of transformational leadership on teachers' job satisfaction, organizational commitment and organizational citizenship behaviour in Tanzanian primary and secondary schools. (Ph. D Dissertation), Radboud University Nijmegen, Netherlands. 
Pozdeeva, E. S. (2019). STUDENTSTIME MANAGEMENT IN HIGHER EDUCATION: REVIEW OF THE LITERATURE. Наука и человечество, 1(1), 65-99.

Rabin, L., \& Fogel, J. N.-U. (2011). Academic procrastination in college students: The role of selfreported executive function. Journal of Clinical and Experimental Neuropsychology, 33, 344357.

Seo, E. (2012). Cramming, active procrastination and academic achievement. Journal of Social Behaviour and Personality, 40, 1333-1340.

Tesfaw, T. A. (2014). The relationship between transformational leadership and job satisfaction: The case of government secondary school teachers in Ethiopia. Educational Management Administration \& Leadership, 42(6), 903-918.

Trueman, M., \& Hartley, J. (1996). A comparison between the time-management skills and academic performance of mature and traditional-entry university students. Higher education, 32(2), 199215. 